\title{
Myocardial Strain Imaging in Resistant Hypertension
}

\author{
Reem Alsharari ${ }^{1,2,3} \cdot$ David Oxborough $^{2} \cdot$ Gregory Y. H. Lip ${ }^{2,4} \cdot$ Alena Shantsila $^{2}$ (D)
}

Accepted: 22 April 2021 / Published online: 5 May 2021

(C) Crown 2021

\begin{abstract}
Purpose of Review Resistant hypertension (RH) is a major contributor to cardiovascular diseases and is associated with increased all-cause and cardiovascular mortality. Cardiac changes such as impaired left ventricular (LV) function, left ventricular hypertrophy (LVH), myocardial fibrosis, and enlarged left atrium (LA) are consequences of chronic exposure to an elevated blood pressure. The purpose of this review article is to demonstrate the potential benefits of using STE as a non-invasive imaging technique in the assessment of cardiac remodeling in patients with hypertension and specifically in uncontrolled and RH population.

Recent Findings It is well-recognized that conventional transthoracic echocardiography is a useful analytic imaging modality to evaluate hypertension-mediated organ damage (HMOD) and in a resistant hypertensive population. More recently twodimensional speckle tracking echocardiography (STE) has been utilized to provide further risk assessment to this population. Summary Recent data has shown that STE is a new promising echocardiographic marker to evaluate early stage LV dysfunction and myocardial fibrosis over conventional 2D parameters in patients with cardiovascular diseases.
\end{abstract}

Keywords Speckle tracking · Deformation imaging · Systolic dysfunction · Uncontrolled hypertension · Resistant hypertension · High blood pressure

\section{Introduction}

Hypertension (HTN) remains the leader of cardiovascular mortality among several risk factors [1]. It has been reported to be responsible for increased incidence of heart failure (HF), cardiovascular comorbidities, and stroke [2-5]. Despite advances in diagnosis and management strategies of HTN, uncontrolled HTN remains a challenging problem and is considered as a primary cause of death for 7.5

This article is part of the Topical Collection on Resistant Hypertension

Alena Shantsila

s.shantsila@liverpool.ac.uk

1 Institute of Cardiovascular Sciences, University of Birmingham, Birmingham, UK

2 Liverpool Centre for Cardiovascular Science, University of Liverpool, Liverpool Heart \& Chest Hospital and Liverpool John Moores University, Liverpool, UK

3 College of Applied Medical Sciences, King Saud Bin Abdulaziz University for Health Sciences, Riyadh, Kingdom of Saudi Arabia

4 Aalborg Thrombosis Research Unit, Department of Clinical Medicine, Aalborg University, Aalborg, Denmark million people each year globally [6]. Resistant hypertension (RH) is defined as office systolic and diastolic blood pressure exceeding $140 \mathrm{mmHg}$ and $90 \mathrm{mmHg}$, respectively, in spite of the concurrent use of three or more antihypertensive agents, one of which being a diuretic [7]. Patients with confirmed $\mathrm{RH}$ are estimated to experience $50 \%$ more cardiovascular events compared to controlled HTN [8].

Impaired left ventricular (LV) function, left ventricular hypertrophy (LVH), and myocardial fibrosis are recognized markers of target organ damage, compromised in patients with long standing HTN [9-11]. However, the relationship between HTN and cardiac remodeling is not completely identified [12]. Conventional two-dimensional (2D) echocardiography provides useful structural and hemodynamic findings that are potent predictors of poor prognosis associated with HTN. Speckle tracking echocardiography (STE) has emerged as a non-invasive and sensitive method for detection of early regional and global myocardial dysfunction that are undetected by conventional parameters in both symptomatic and asymptomatic patients with cardiovascular disease [13•]. This review aims to comprehensively assess the literature on potential benefits of STE use in the evaluation of cardiac remodeling in patients with uncontrolled HTN and RH. 


\section{Principle of LV Function Quantification by Speckle Tracking Echocardiography}

Myocardial strain refers to the percentage deformation of the myocardium during the cardiac cycle. It represents the extent of regional myocardial deformation in a specified period of time in three orthogonal directions (longitudinal, radial, and circumferential). All were determined by length, thickness, and shortening, using the formula $\varepsilon=(\mathrm{L}-\mathrm{Lo}) / \mathrm{Lo}$, where $\varepsilon$ indicates strain (has a unit of \%), L indicates length after deformation, and Lo indicates baseline length. Strain rate (SR) refers to the speed at which the myocardium deforms (velocity changes/distance) [13•].

Initially, two techniques were introduced to assess myocardial strain: (i) cardiac magnetic resonance (CMR) in the late 1980s [14 ] and (ii) tissue Doppler imaging (TDI) in the 1990s [15]. While TDI is considered a feasible and reliable technique, it has several limitations that still remain unresolved. TDI is highly angle dependent, is constrained to longitudinal cardiac deformation, and suffers from poor signal to noise ratio [16]. STE is a promising technique which was introduced in the early 2000s [17] and has been validated against sonomicrometry (which involves the implantation of piezoelectric crystals and measures of the changes in distance between embedded crystals, due to the myocardium movement) and tagged CMR $[18,19 \bullet]$. It is used to assess myocardial function, and it overcomes the limitations of TDI [20].

The main advantage of STE is its ability to reflect active contraction within each segment, avoiding tethering effect, which makes it less influenced by artefacts. It can measure three directions of cardiac motion and can track the speckle in any 2D direction, making it less angle dependent (Fig. 1).

Heterogeneous ultrasound-myocardial tissue interactions produce an interference pattern, which is identified as a unique stable set of speckles [21]. STE modality identifies speckles based on echocardiographic images and tracks them between consecutive frames. It includes evaluation of myocardial strain, strain rate, and rotational deformation, which all are obtained by using specific software [22].

Myocardial strain derived from STE can be measured in 3 planes. Circumferential and longitudinal strains represent a shortening of the LV cavity, and both have negative values (Fig. 2). Radial strain represents myocardial thickening of the LV in systole (secondary to the conservation of mass from longitudinal and circumferential shortening) and is denoted as a positive value. All strain parameters can be evaluated globally or regionally. Global longitudinal strain (GLS), global circumferential strain (GCS), and global radial strain (GRS) are calculated as an average of segmental regional strain. The average normal GLS is $-19.7 \%$ [23•], with a borderline level of $-18 \%$ $[23 \cdot, 24]$. Normal GCS is considered to be between -20.9 and $-27.8 \%$, and average GRS is between 35.1 and $59.0 \%$ [23 ${ }^{\circ}$. STE also provides the capacity to measure twist and torsion which are the parameters to determine deformation of LV [17].

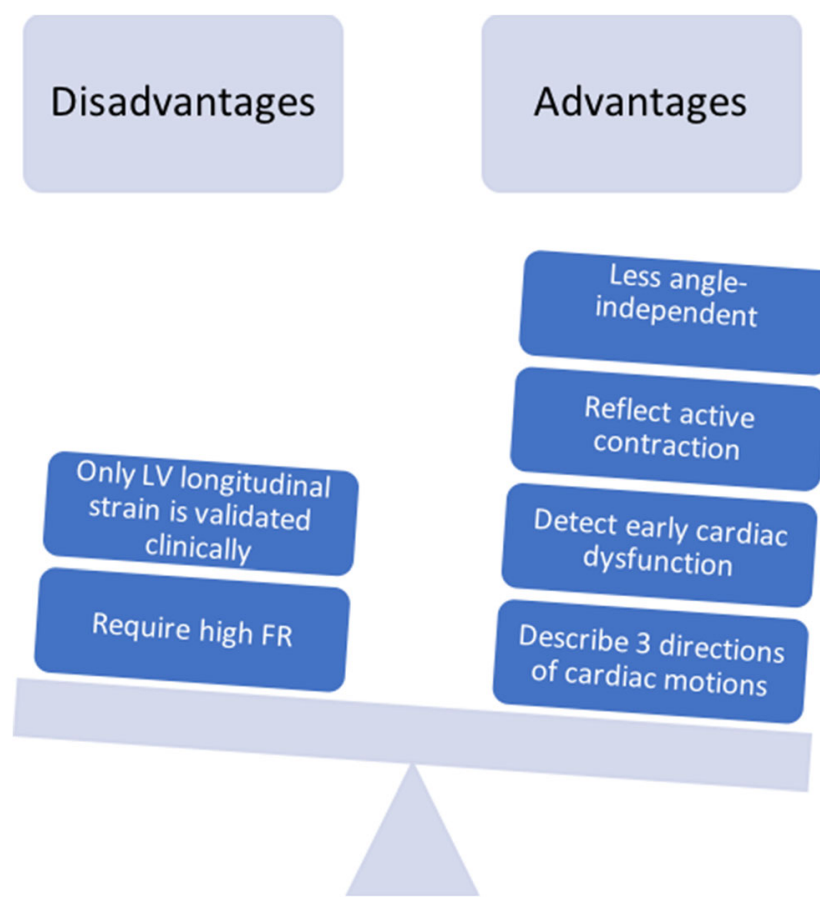

Fig. 1 Speckle tracking echocardiography advantages. LV, left ventricular; FR, frame rate

\section{The Role of Strain in Predicting Early Damage in Hypertension}

Conventional echocardiography is a reliable method widely used to detect impaired LV systolic and diastolic function in HTN. It is also used to calculate LV mass and determine the presence and the degree of $\mathrm{LVH}$, a predictor of morbidity and mortality in HTN $[25,26]$.

However, it has been shown that HTN is associated with reduction in LV systolic strain in asymptomatic patients with normal ejection fraction (EF) with and without LVH, suggesting that LV mechanical abnormalities precede the development of LVH [27-29].

\section{Decreased Longitudinal Function in Hypertension}

Normal myocardium consists of cardiac myocytes (30-40\%) and non-myocyte components (60-70\%) [30]. Myocardial fibers in the subendocardial layer are oriented in a longitudinal direction which then gradually change to a transverse direction in the middle layer and revert to longitudinal in the subepicardial layer [30].

Recent studies [28, 31-33] have closely linked the presence of fibrosis to attenuated myocardial strain. Cardiac remodeling in HTN involves an imbalance in the production of collagen types I and III (these subtypes are the major stress-bearing element within the ECM). This leads to an excessive deposition of collagen fibers in fibroblasts which transdifferentiate into myofibroblasts leading to 

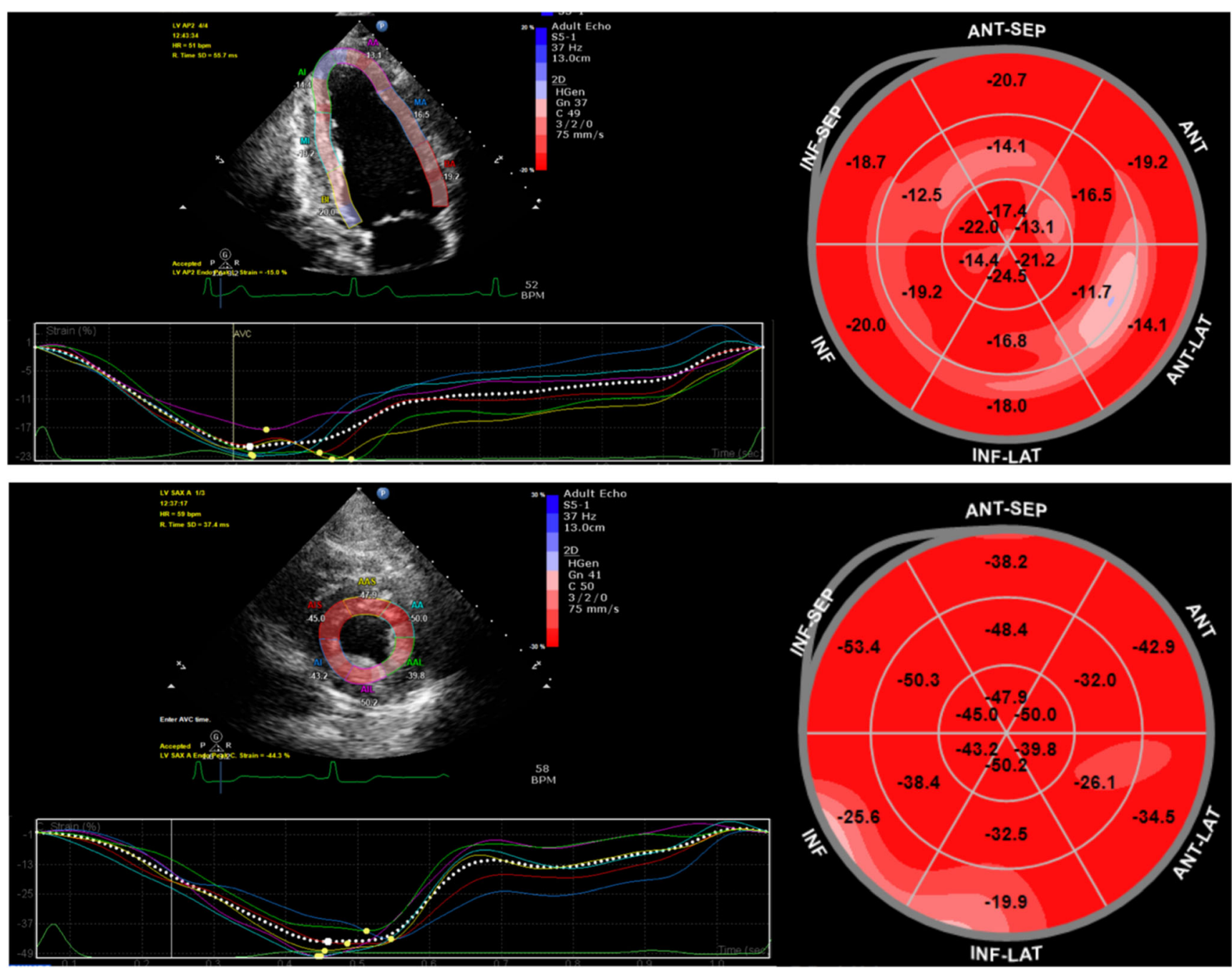

Fig. 2 Example of GLS (upper) and GCS (lower) of LV. GCS global circumferential strain; GLS global longitudinal strain; $L V$ left ventricular

heterogeneous acceleration of myocardial fibrosis [34, 35]. Moreover, it has been reported that increased matrix metalloproteinase-1 (MMP-1) turnover lead to reduced collagen I and III degradation and development of subendocardial myocardial fibrosis. This implies that irregular collagen production and myocardial fibrosis are associated with reduced GLS in HTN and hypertrophic cardiomyopathy $[28,31]$ and eventually lead to early impairment of systolic function $[28,32,33]$. Another pathway leading to activation of subendocardial production of collagen in HTN is pressure overload and high-end-systolic wall stress. The process involves collagen network thickening [36] and fibrosis build up primarily in the subendocardial layer.

Furthermore, fibrosis may have a possible direct effect on the rearrangement of myocardial sheets in subendocardial layers $[30,37]$ where maximum shearing deformation occurs, compared to the other layers $[38,39]$. There is limited information available linking cardiac shear motion and systolic function.

\section{The Additive Value of Global Longitudinal Strain}

Longitudinal, circumferential, and radial dysfunction do not occur in tandem with longitudinal subendocardial fibers being prone to being compromised first in several pathologies [40, 41]. GLS is the most widely used clinical application of STE. It has been recommended by the American Society of Echocardiography (ASE) for evaluation of global LV systolic function [13•] and has been widely validated [42, 43]. It is considered a strong indicator of an early phase of myocardial impairment in HTN as shown in Table 1 [29, 44-51]. It has been shown in some studies that the prevalence percentage of impaired GLS in hypertensive population vary between 15 and $42 \%$ [44, 52-54], suggesting for the influence of other related factors such as age, gender [55, 56], ethnicity, duration of the HTN, uncontrolled HTN [52-54], diabetes, and obesity [44].

Studies have shown that GLS might be beneficial as an independent predictor of cardiovascular outcomes in general population [57-59] and in a population with a wide range of $\mathrm{EF}[60]$. It is a strong predictor of major adverse cardiac events 
Table 1 Summary of studies using a two-dimensional speckle tracking analysis in hypertensive populations

\begin{tabular}{|c|c|c|c|c|c|c|c|}
\hline Author/year & Methods & Patient population & $\begin{array}{l}\text { Sample } \\
\text { size }\end{array}$ & $\begin{array}{l}\text { STE software/ } \\
\text { echo machine }\end{array}$ & STE parameters & $\begin{array}{l}\text { Follow- } \\
\text { up } \\
\text { period }\end{array}$ & Results \\
\hline $\begin{array}{l}\text { Bendiab et al., } \\
2017 \text { [44] }\end{array}$ & 2D STE & $\begin{array}{l}\text { HTN/overweight } \\
\text { HTN/diabetes } \\
\text { HTN/dyslipidemia } \\
\text { Uncontrolled HTN }\end{array}$ & 200 & EchoPAC, GE & GLS & 1 year & $\begin{array}{l}\downarrow \text { GLS in uncontrolled HTN } \\
\downarrow \text { GLS in long lasting HTN } \\
\quad(>10 \text { years })\end{array}$ \\
\hline $\begin{array}{l}\text { Saito et al., } \\
\quad 2016[45]\end{array}$ & 2D STE & $\begin{array}{l}\text { HTN without ischemic heart } \\
\text { disease }\end{array}$ & 388 & TomTec, GE & GLS & 4 years & $\downarrow$ GLS predicts MACE \\
\hline $\begin{array}{l}\text { Lee et al., } 2016 \\
\quad[46]\end{array}$ & 2D STE & HTN & 95 & EchoPAC, GE & $\begin{array}{l}\text { Subendocardial LS } \\
\text { Subepicardial LS }\end{array}$ & $\begin{array}{c}7.3 \pm 2.0 \\
\text { years }\end{array}$ & $\begin{array}{l}\downarrow \text { subepicardial LS } \\
\text { Preserved subendocardial } \\
\quad \text { LS }\end{array}$ \\
\hline $\begin{array}{l}\text { Chen et al., } \\
2016 \text { [47] }\end{array}$ & 2D STE & $\begin{array}{l}\text { Controlled HTN (group 1) } \\
\text { Uncontrolled HTN (group2) } \\
\text { Healthy control (group 3) }\end{array}$ & 361 & QLAB, Philips & $\begin{array}{l}\text { cEss } \\
\text { MWFs } \\
\text { LS } \\
\text { CS } \\
\text { RS }\end{array}$ & 3 months & $\begin{array}{l}\downarrow \text { myocardial function in } \\
\text { group } 2 \text { vs. groups } 1 \text { and } \\
3\end{array}$ \\
\hline $\begin{array}{r}\text { Cheng et al., } \\
2014[48]\end{array}$ & 2D STE & $\begin{array}{l}\text { Intensive treatment with SBP } \\
\text { target }<130 \mathrm{mmHg} \text { (group 1) } \\
\text { Standard treatment with SBP } \\
\text { target }<140 \mathrm{mmHg} \text { (group 2) }\end{array}$ & 182 & TomTec & GLS & 24 weeks & $\begin{array}{l}\text { After therapy: } \\
\uparrow \text { GLS in group } 1 \\
\uparrow \text { GLS in lower BMI } \\
\uparrow \text { GLS in women }\end{array}$ \\
\hline $\begin{array}{l}\text { Dobrowolski } \\
\text { et al., } 2014 \\
\text { [49] }\end{array}$ & 2D STE & $\begin{array}{l}\mathrm{RH} \\
\mathrm{OSA}^{-} / \mathrm{MS}^{-}(\text {group } 1) \\
\mathrm{OSA}^{+} / \mathrm{MS}^{-}(\text {group } 2) \\
\mathrm{OSA}^{-} / \mathrm{MS}^{+}(\text {group } 3) \\
\mathrm{OSA}^{+} / \mathrm{MS}^{+}(\text {group } 4)\end{array}$ & 155 & EchoPAC, GE & GLS & - & $\begin{array}{l}\downarrow \text { GLS in group } 4 \text { vs. groups } \\
1,2 \text {, and } 3\end{array}$ \\
\hline $\begin{array}{l}\text { Imbalzano } \\
\quad \text { et al., } 2011 \\
\text { [10] }\end{array}$ & 2D STE & $\begin{array}{l}\text { HTN/LVH (group 1) } \\
\text { HTN/no LVH (group 2) } \\
\text { Healthy control (group 3) }\end{array}$ & 102 & EchoPAC, GE & $\begin{array}{l}\text { GLS } \\
\text { GCS } \\
\text { GRS }\end{array}$ & - & $\begin{array}{l}\downarrow \text { GLS in groups } 1 \text { and } 2 \text { vs. } \\
\quad \text { group } 3\end{array}$ \\
\hline
\end{tabular}

$2 D$ STE Two-dimensional speckle tracking echocardiography, $A F I$ automatic function imaging, $B M I$ body mass index, $c E S S$, circumferential endsystolic wall stress, $C S$ circumferential strain, $E F$ ejection fraction, $G C S$ global circumferential strain, $G E$ general electric, $G L S$ global longitudinal strain, IVSDd interventricular septal diastolic diameter, $L S$ longitudinal strain, $L V H$ left ventricle hypertrophy, $M A C E$ major adverse cardiac events, $M W F S$ midwall fraction shortening, $M S^{-}$without metabolic syndrome, $M S^{+}$with metabolic syndrome, $O S A^{-}$without obstructive sleep apnea, $O S A^{+}$with obstructive sleep apnea, $P W D d$ posterior wall diastolic diameter, $R D N$ renal denervation, $R H$ resistant hypertension, $R S$ radial strain, $R W T$ relative wall thickness, $\downarrow$ significant reduction, $\uparrow$ significant increase

(MACE) including HF, stroke, myocardial infraction (MI), and all-cause mortality $[45,61,62]$. In the Copenhagen City Heart Study [62], which includes 1296 of participants from general population, who underwent STE assessment between 2001 and 2003 and were followed until 2013, GLS was an independent predictor of cardiovascular death and morbidity, including HF and MI with a hazard ratio of 1.12 [1.08-1.17] $(p<0.001$ per $1 \%$ decrease). This association persisted after multivariable adjustment for the following parameters: (age, gender, heart rate, HTN, systolic blood pressure, LVEF, LV mass index, LV dimension, deceleration time, LA dimension and E/e). [62] Similarly, Saito et al. [45] retrospectively collected data on MACE (all-cause death and admission because of HF, MI, and strokes, with a median follow-up 4 years) in asymptomatic non-ischemic subjects with high blood pressure. It has been shown that MACE occurrence was independently associated with greater incidence of concentric hypertrophy and reduced GLS (both $p<0.01$ ).

Cheng et al. [48] examined whether systolic dysfunction assessed by STE improved by intensive antihypertensive treatment in 182 patients with uncontrolled HTN. The study assessed GLS before and after 24 weeks of antihypertensive treatment and showed an improvement in GLS in response to the treatment that was independent of changes in blood pressure and associated with increased dose. This is more likely to occur when afterload reducing treatment is used, which improves LV function independent of blood pressure readings [63]. Moreover, GLS improved by $-1.4 \%$ more in uncontrolled hypertensive not meeting RH criteria females compared to uncontrolled hypertensive males $(p=0.003)$. This difference in the responses between the two genders could be due to the differences in GLS baseline values, where females had higher GLS compared to males. In addition, the association between female gender and improvement in GLS is unclear and has yet to be examined in the general population to confirm sex differences associated with LV function. Another observation found an improvement in GLS by $-0.46 \%$ for every $5 \mathrm{~kg} / \mathrm{m}^{2}$ reduction in body mass index (BMI) $(p=0.015)$.

Similar findings have been reported by other studies $[64,65]$ which links attenuated GLS with metabolic disorders and 
obesity. RESOLVE trail [64] examined participants with metabolic syndrome and showed reduced GLS compared to a control group, while Wong et al. [65] have shown that insulin and BMI are significantly and independently associated with strain function in obese population. However, in Crendal et al.'s study [64], 78\% of participants had HTN which may consider as a confounding factor and could mask the actual association. In addition, $17 \%$ of participants were treated with beta-blockers, which have an established effect on LV remodeling.

\section{Circumferential and Radial Function}

Notably, the mid-myocardial layer may remain unchanged or even increased compared to the longitudinal function, which probably explain the well-preserved function reflected by EF $[29,50,51,66][67,68]$. Preserved radial and circumferential function at early stages of HTN linked to the cross-fiber shortening phenomenon from hypertension-related ventricular remodeling, where mid-wall myocardial fibers are not compromised and consequently circumferential and radial function are preserved [54]. Although this explanation has received reasonable attention, other theories suggest that reduced longitudinal and circumferential strain exists with preserved EF secondary to increased LV wall thickness [68].

However, longitudinal function is not always the earliest predictor in all circumstances. Previous studies have reported that all three planes of function (longitudinal, radial, and circumferential) may decline in HF, signifying a decompensation mechanism of the LV and impaired myocardial layers as a response to increase myocardial wall stress and disease progress [66, 69, 70]. This happens because the impairment of longitudinal function occurs in the earlier phases of the remodeling, followed by decrease in radial and circumferential function, which is associated with further LV dilatation leading to HF [71-73].

\section{Twist and Torsion Deformation}

Rotation, twist, and torsion are several terms to describe additional deformation of the LV caused by the helical arrangement of myocardial fibers. LV rotation is defined as an apical counterclockwise movement and basal clockwise movement in systole. During systole, the LV stores potential energy, which is subsequently released in early diastole. Twist and untwist play an important role by storing and releasing this energy which leads to LV diastolic relaxation and early diastolic filling. Twist/untwist $\left({ }^{\circ}\right)$ and rate $(\%)$ are calculated as the net difference between basal clockwise and apical anticlockwise rotation and rotation rate [17]. Torsion is calculated by dividing the twist angle by apical-basal distance and measured in $\% \mathrm{~cm} \mathrm{[17].} \mathrm{In} \mathrm{a} \mathrm{non-diseased} \mathrm{population,} \mathrm{LV} \mathrm{twist} \mathrm{is}$ approximately $15^{\circ}$ with apical rotation being between $5^{\circ}$ and $10^{\circ}$ (counterclockwise) and basal rotation between $-4^{\circ}$ and $-7^{\circ}$ (clockwise) as observed in studies by CMR tagging [74]. A study by Dong et al. [75] showed that as with other indices of cardiac function, rotation is affected by loading condition (preload and afterload) of LV. Rotation increases with increased preload (end-diastolic volumes) and decreased afterload (end-systolic volumes) [75]. Reduced LV untwisting, elevated torsion, and twist have been observed in hypertensive patients [10, 76-78] and in various cardiovascular diseases [79, 80]. Alterations of myocardial twist are also linked to aging. Previous studies have demonstrated decreased diastolic untwisting, increased LV rotation, and twist with age in a normal population [81].

\section{Conclusion}

Myocardial fiber orientation is a fundamental feature of the myocardium, and it has a substantial role in systolic function. STE imaging is a new non-invasive cardiovascular imaging modality that can be used in clinical practice to understand the mechanism of cardiac deformation, particularly in patients with early compensation of myocardial function and in patients with RH. Using STE also offers comprehensive evaluation to detect the underlying impaired systolic function in several pathologies, including HTN, to deliver optimal management plan. Furthermore, this powerful and valuable technique provides accurate and objective measures on global/ regional contractile function.

Funding This study is supported by the King Saud Bin Abdulaziz University for Health Sciences, Riyadh, Kingdom of Saudi Arabia.

Availability of Data and Material Not applicable

Code Availability Not applicable.

\section{Declarations}

Conflict of Interest The authors declare no conflicts of interest relevant to this manuscript.

Human and Animal Rights and Informed Consent This article does not contain any studies with human or animal subjects performed by any of the authors.

Open Access This article is licensed under a Creative Commons Attribution 4.0 International License, which permits use, sharing, adaptation, distribution and reproduction in any medium or format, as long as you give appropriate credit to the original author(s) and the source, provide a link to the Creative Commons licence, and indicate if changes were made. The images or other third party material in this article are included in the article's Creative Commons licence, unless indicated otherwise in a credit line to the material. If material is not included in the article's Creative Commons licence and your intended use is not permitted by statutory regulation or exceeds the permitted use, you will need to obtain permission directly from the copyright holder. To view a copy of this licence, visit http://creativecommons.org/licenses/by/4.0/. 


\section{References}

Papers of particular interest, published recently, have been highlighted as:

- Of importance

1. Roth GA, Mensah GA, Johnson CO, Addolorato G, Ammirati E, Baddour LM, et al. Global burden of cardiovascular diseases and risk factors, 1990-2019: update from the GBD 2019 study. J Am Coll Cardiol. 2020;76(25):2982-3021. https://doi.org/10.1016/j.jacc.2020.11. 010.

2. Drazner MH. The progression of hypertensive heart disease. Circulation. 2011;123(3):327-34. https://doi.org/10.1161/ CIRCULATIONAHA.108.845792.

3. Kannel WB, Castelli WP, McNamara PM, McKee PA, Feinleib M. Role of blood pressure in the development of congestive heart failure. The Framingham study. N Engl J Med. 1972;287(16):781-7. https://doi.org/10.1056/NEJM197210192871601.

4. Messerli FH, Williams B, Ritz E. Essential hypertension. Lancet. 2007;370(9587):591-603. https://doi.org/10.1016/S0140-6736(07) 61299-9.

5. Tocci G, Sciarretta S, Volpe M. Development of heart failure in recent hypertension trials. J Hypertens. 2008;26(7):1477-86. https://doi.org/10.1097/HJH.0b013e3282fe1d3d.

6. Alwan A, et al. Global status report on noncommunicable diseases 2010. World Health Organization. 2011; April. https://www.who. int/nmh/publications/ncd_report2010/en/.

7. Williams B, Mancia G, Spiering W, Agabiti Rosei E, Azizi M, Burnier M, et al. 2018 ESC/ESH Guidelines for the management of arterial hypertension. Eur Heart J. 2018;39(33):3021-104. https://doi.org/10.1093/eurheartj/ehy339.

8. Daugherty SL, Powers JD, Magid DJ, Tavel HM, Masoudi FA, Margolis KL, et al. Incidence and prognosis of resistant hypertension in hypertensive patients. Circulation. 2012;125(13):1635-42. https://doi.org/10.1161/CIRCULATIONAHA.111.068064.

9. Marwick TH, Gillebert TC, Aurigemma G, Chirinos J, Derumeaux G, Galderisi M, et al. Recommendations on the use of echocardiography in adult hypertension: a report from the European Association of Cardiovascular Imaging (EACVI) and the American Society of Echocardiography (ASE)dagger. Eur Heart J Cardiovasc Imaging. 2015;16(6):577-605. https://doi.org/10.1093/ehjci/jev076.

10. Imbalzano E, Zito C, Carerj S, Oreto G, Mandraffino G, CusmaPiccione $\mathrm{M}$, et al. Left ventricular function in hypertension: new insight by speckle tracking echocardiography. Echocardiography. 2011;28(6): 649-57. https://doi.org/10.1111/j.1540-8175.2011.01410.x.

11. Cikes M, Sutherland GR, Anderson LJ, Bijnens BH. The role of echocardiographic deformation imaging in hypertrophic myopathies. Nat Rev Cardiol. 2010;7(7):384-96. https://doi.org/10.1038/ nrcardio.2010.56.

12. Narayanan A, Aurigemma GP, Chinali M, Hill JC, Meyer TE, Tighe DA. Cardiac mechanics in mild hypertensive heart disease: a specklestrain imaging study. Circ Cardiovasc Imaging. 2009;2(5):382-90. https://doi.org/10.1161/CIRCIMAGING.108.811620.

13. Lang RM, Badano LP, Mor-Avi V, Afilalo J, Armstrong A, Ernande L, et al. Recommendations for cardiac chamber quantification by echocardiography in adults: an update from the American Society of Echocardiography and the European Association of Cardiovascular Imaging. J Am Soc Echocardiogr. 2015;28(1):139 e14. https://doi.org/10.1016/j.echo.2014.10.003 The paper provided updated information about deformation imaging and strain rate.

14. Zerhouni EA, Parish DM, Rogers WJ, Yang A, Shapiro EP. Human heart: tagging with MR imaging-a method for noninvasive assessment of myocardial motion. Radiology. 1988;169(1):59-63. https:// doi.org/10.1148/radiology.169.1.3420283 This was the first study that introduced the myocardial strain technique using cardiac magnetic resonance in the late $1980 \mathrm{~s}$.

15. Heimdal A, Stoylen A, Torp H, Skjaerpe T. Real-time strain rate imaging of the left ventricle by ultrasound. J Am Soc Echocardiogr. 1998;11(11):1013-9. https://doi.org/10.1016/s0894-7317(98)70151-8.

16. Dandel M, Lehmkuhl H, Knosalla C, Suramelashvili N, Hetzer R. Strain and strain rate imaging by echocardiography - basic concepts and clinical applicability. Curr Cardiol Rev. 2009;5(2):133-48. https://doi.org/10.2174/157340309788166642.

17. D'Hooge J, Heimdal A, Jamal F, Kukulski T, Bijnens B, Rademakers $\mathrm{F}$, et al. Regional strain and strain rate measurements by cardiac ultrasound: principles, implementation and limitations. Eur J Echocardiogr. 2000;1(3):154-70. https://doi.org/10.1053/euje.2000.0031.

18. Cho GY, Chan J, Leano R, Strudwick M, Marwick TH. Comparison of two-dimensional speckle and tissue velocity based strain and validation with harmonic phase magnetic resonance imaging. Am J Cardiol. 2006;97(11):1661-6. https://doi.org/10.1016/j.amjcard. 2005.12.063.

19. Amundsen BH, Helle-Valle T, Edvardsen T, Torp H, Crosby J, Lyseggen E, et al. Noninvasive myocardial strain measurement by speckle tracking echocardiography: validation against sonomicrometry and tagged magnetic resonance imaging. J Am Coll Cardiol. 2006;47(4):789-93. https://doi.org/10.1016/j.jacc. 2005.10.040 This study showed the validation of STE against sonomicrometry and tagged CMR.

20. Reisner SA, Lysyansky P, Agmon Y, Mutlak D, Lessick J, Friedman Z. Global longitudinal strain: a novel index of left ventricular systolic function. J Am Soc Echocardiogr. 2004;17(6):630 3. https://doi.org/10.1016/j.echo.2004.02.011.

21. Mor-Avi V, Lang RM, Badano LP, Belohlavek M, Cardim NM, Derumeaux G, et al. Current and evolving echocardiographic techniques for the quantitative evaluation of cardiac mechanics: ASE/ EAE consensus statement on methodology and indications endorsed by the Japanese Society of Echocardiography. J Am Soc Echocardiogr. 2011;24(3):277-313. https://doi.org/10.1016/j.echo.2011.01.015.

22. Geyer H, Caracciolo G, Abe H, Wilansky S, Carerj S, Gentile F, et al. Assessment of myocardial mechanics using speckle tracking echocardiography: fundamentals and clinical applications. J Am Soc Echocardiogr. 2010;23(4):351-69; quiz 453-5. https://doi.org/ 10.1016/j.echo.2010.02.015.

23. Yingchoncharoen T, Agarwal S, Popovic ZB, Marwick TH. Normal ranges of left ventricular strain: a meta-analysis. J Am Soc Echocardiogr. 2013;26(2):185-91. https://doi.org/10.1016/j. echo.2012.10.008 This was the first meta-analysis on the normal range of global strain.

24. Negishi T, Negishi K, Thavendiranathan P, Cho GY, Popescu BA, Vinereanu D, et al. Effect of experience and training on the concordance and precision of strain measurements. JACC Cardiovasc Imaging. 2017;10(5):518-22. https://doi.org/10.1016/j.jcmg.2016.06.012.

25. Kehat I, Molkentin JD. Molecular pathways underlying cardiac remodeling during pathophysiological stimulation. Circulation. 2010;122(25):2727-35. https://doi.org/10.1161/ CIRCULATIONAHA.110.942268.

26. Levy D, Garrison RJ, Savage DD, Kannel WB, Castelli WP. Prognostic implications of echocardiographically determined left ventricular mass in the Framingham Heart Study. N Engl J Med. 1990;322(22):1561-6. https://doi.org/10.1056/ NEJM199005313222203.

27. Rosen BD, Saad MF, Shea S, Nasir K, Edvardsen T, Burke G, et al. Hypertension and smoking are associated with reduced regional left ventricular function in asymptomatic: individuals the Multi-Ethnic Study of Atherosclerosis. J Am Coll Cardiol. 2006;47(6):1150-8. https://doi.org/10.1016/j.jacc.2005.08.078.

28. Kang SJ, Lim HS, Choi BJ, Choi SY, Hwang GS, Yoon MH, et al. Longitudinal strain and torsion assessed by two-dimensional 
speckle tracking correlate with the serum level of tissue inhibitor of matrix metalloproteinase-1, a marker of myocardial fibrosis, in patients with hypertension. J Am Soc Echocardiogr. 2008;21(8):90711. https://doi.org/10.1016/j.echo.2008.01.015.

29. Kouzu H, Yuda S, Muranaka A, Doi T, Yamamoto H, Shimoshige S, et al. Left ventricular hypertrophy causes different changes in longitudinal, radial, and circumferential mechanics in patients with hypertension: a two-dimensional speckle tracking study. J Am Soc Echocardiogr. 2011;24(2):192-9. https://doi.org/10.1016/j.echo.2010. 10.020 .

30. Weber KT, Brilla CG. Pathological hypertrophy and cardiac interstitium. Fibrosis and renin-angiotensin-aldosterone system. Circulation. 1991;83(6):1849-65. https://doi.org/10.1161/01.cir.83.6.1849.

31. Martinez DA, Guhl DJ, Stanley WC, Vailas AC. Extracellular matrix maturation in the left ventricle of normal and diabetic swine. Diabetes Res Clin Pract. 2003;59(1):1-9. https://doi.org/10.1016/ s0168-8227(02)00178-x.

32. Brilla CG, Janicki JS, Weber KT. Impaired diastolic function and coronary reserve in genetic hypertension. Role of interstitial fibrosis and medial thickening of intramyocardial coronary arteries. Circ Res. 1991;69(1):107-15. https://doi.org/10.1161/01.res.69.1.107.

33. Komuro I, Katoh Y, Kaida T, Shibazaki Y, Kurabayashi M, Hoh E, et al. Mechanical loading stimulates cell hypertrophy and specific gene expression in cultured rat cardiac myocytes. Possible role of protein kinase C activation. J Biol Chem. 1991;266(2):1265-8.

34. Shahbaz AU, Sun Y, Bhattacharya SK, Ahokas RA, Gerling IC, McGee JE, et al. Fibrosis in hypertensive heart disease: molecular pathways and cardioprotective strategies. J Hypertens. 2010;28(Suppl 1):S25-32. https://doi.org/10.1097/01.hjh. 0000388491.35836.d2.

35. Bruder O, Wagner A, Jensen CJ, Schneider S, Ong P, Kispert EM, et al. Myocardial scar visualized by cardiovascular magnetic resonance imaging predicts major adverse events in patients with hypertrophic cardiomyopathy. J Am Coll Cardiol. 2010;56(11):87587. https://doi.org/10.1016/j.jacc.2010.05.007.

36. LeGrice IJ, Pope AJ, Sands GB, Whalley G, Doughty RN, Smaill $\mathrm{BH}$. Progression of myocardial remodeling and mechanical dysfunction in the spontaneously hypertensive rat. Am J Physiol Heart Circ Physiol. 2012;303(11):H1353-65. https://doi.org/10. 1152/ajpheart.00748.2011.

37. Chen J, Liu W, Zhang H, Lacy L, Yang X, Song SK, et al. Regional ventricular wall thickening reflects changes in cardiac fiber and sheet structure during contraction: quantification with diffusion tensor MRI. Am J Physiol Heart Circ Physiol. 2005;289(5):H1898907. https://doi.org/10.1152/ajpheart.00041.2005.

38. LeGrice IJ, Takayama Y, Covell JW. Transverse shear along myocardial cleavage planes provides a mechanism for normal systolic wall thickening. Circ Res. 1995;77(1):182-93. https://doi.org/10. 1161/01.res.77.1.182.

39. Ishizu T, Seo Y, Kameda Y, Kawamura R, Kimura T, Shimojo N, et al. Left ventricular strain and transmural distribution of structural remodeling in hypertensive heart disease. Hypertension. $2014 ; 63$ (3):500-6. https://doi.org/10.1161/ HYPERTENSIONAHA.113.02149.

40. Sengupta PP, Krishnamoorthy VK, Korinek J, Narula J, Vannan MA, Lester SJ, et al. Left ventricular form and function revisited: applied translational science to cardiovascular ultrasound imaging. J Am Soc Echocardiogr. 2007;20(5):539-51. https://doi.org/10. 1016/j.echo.2006.10.013.

41. Hung CL, Verma A, Uno H, Shin SH, Bourgoun M, Hassanein AH, et al. Longitudinal and circumferential strain rate, left ventricular remodeling, and prognosis after myocardial infarction. J Am Coll Cardiol. 2010;56(22):1812-22. https://doi.org/10.1016/j.jacc.2010.06.044.

42. Buchalter MB, Weiss JL, Rogers WJ, Zerhouni EA, Weisfeldt ML, Beyar R, et al. Noninvasive quantification of left ventricular rotational deformation in normal humans using magnetic resonance imaging myocardial tagging. Circulation. 1990;81(4):1236-44.

43. Yeon SB, Reichek N, Tallant BA, Lima JA, Calhoun LP, Clark NR, et al. Validation of in vivo myocardial strain measurement by magnetic resonance tagging with sonomicrometry. J Am Coll Cardiol. 2001;38(2):555-61.

44. Soufi Taleb Bendiab N, Meziane-Tani A, Ouabdesselam S, Methia N, Latreche S, Henaoui L, et al. Factors associated with global longitudinal strain decline in hypertensive patients with normal left ventricular ejection fraction. Eur J Prev Cardiol. 2017;24(14): 1463-72. https://doi.org/10.1177/2047487317721644.

45. Saito M, Khan F, Stoklosa T, Iannaccone A, Negishi K, Marwick TH. Prognostic implications of LV strain risk score in asymptomatic patients with hypertensive heart disease. JACC Cardiovasc Imaging. 2016;9(8):911-21. https://doi.org/10.1016/j.jcmg.2015.09.027.

46. Lee WH, Liu YW, Yang LT, Tsai WC. Prognostic value of longitudinal strain of subepicardial myocardium in patients with hypertension. J Hypertens. 2016;34(6):1195-200. https://doi.org/10. 1097/HJH.0000000000000903.

47. Chen XJ, Sun XL, Zhang Q, Gao XL, Liang YJ, Jiang J, et al. Uncontrolled blood pressure as an independent risk factor of early impaired left ventricular systolic function in treated hypertension. Echocardiography. 2016;33(10):1488-94. https://doi.org/10.1111/ echo. 13289 .

48. Cheng S, Shah AM, Albisu JP, Desai AS, Hilkert RJ, Izzo J, et al. Reversibility of left ventricular mechanical dysfunction in patients with hypertensive heart disease. J Hypertens. 2014;32(12):2479-86; discussion 86-7. https://doi.org/10.1097/HJH.0000000000000340.

49. Dobrowolski P, Klisiewicz A, Florczak E, Prejbisz A, Bielen P, Sliwinski $P$, et al. Independent association of obstructive sleep apnea with left ventricular geometry and systolic function in resistant hypertension: the RESIST-POL study. Sleep Med. 2014;15(11): 1302-8. https://doi.org/10.1016/j.sleep.2014.06.015.

50. Mizuguchi Y, Oishi Y, Miyoshi H, Iuchi A, Nagase N, Oki T. The functional role of longitudinal, circumferential, and radial myocardial deformation for regulating the early impairment of left ventricular contraction and relaxation in patients with cardiovascular risk factors: a study with two-dimensional strain imaging. J Am Soc Echocardiogr. 2008;21(10):1138-44. https://doi.org/10.1016/j. echo.2008.07.016.

51. Koulouris SN, Kostopoulos KG, Triantafyllou KA, Karabinos I, Bouki TP, Karvounis HI, et al. Impaired systolic dysfunction of left ventricular longitudinal fibers: a sign of early hypertensive cardiomyopathy. Clin Cardiol. 2005;28(6):282-6. https://doi.org/10. 1002/clc.4960280605.

52. Sengupta SP, Caracciolo G, Thompson C, Abe H, Sengupta PP. Early impairment of left ventricular function in patients with systemic hypertension: new insights with 2-dimensional speckle tracking echocardiography. Indian Heart J. 2013;65(1):48-52. https:// doi.org/10.1016/j.ihj.2012.12.009.

53. Goncalves S, Cortez-Dias N, Nunes A, Belo A, Zimbarra Cabrita I, Sousa $\mathrm{C}$, et al. Left ventricular systolic dysfunction detected by speckle tracking in hypertensive patients with preserved ejection fraction. Rev Port Cardiol. 2014;33(1):27-37. https://doi.org/10. 1016/j.repc.2013.07.009.

54. Kosmala W, Plaksej R, Strotmann JM, Weigel C, Herrmann S, Niemann M, et al. Progression of left ventricular functional abnormalities in hypertensive patients with heart failure: an ultrasonic two-dimensional speckle tracking study. J Am Soc Echocardiogr. 2008;21(12):1309-17. https://doi.org/10.1016/j.echo.2008.10.006.

55. Andre F, Steen H, Matheis P, Westkott M, Breuninger K, Sander Y, et al. Age- and gender-related normal left ventricular deformation assessed by cardiovascular magnetic resonance feature tracking. J Cardiovasc Magn Reson. 2015;17:25. https://doi.org/10.1186/ s12968-015-0123-3. 
56. Cheng S, Larson MG, McCabe EL, Osypiuk E, Lehman BT, Stanchev P, et al. Age- and sex-based reference limits and clinical correlates of myocardial strain and synchrony: the Framingham Heart Study. Circ Cardiovasc Imaging. 2013;6(5):692-9. https:// doi.org/10.1161/CIRCIMAGING.112.000627.

57. Russo C, Jin Z, Elkind MS, Rundek T, Homma S, Sacco RL, et al. Prevalence and prognostic value of subclinical left ventricular systolic dysfunction by global longitudinal strain in a communitybased cohort. Eur J Heart Fail. 2014;16(12):1301-9. https://oi. org/10.1002/ejhf.154.

58. Cheng S, McCabe EL, Larson MG, Merz AA, Osypiuk E, Lehman BT, et al. Distinct aspects of left ventricular mechanical function are differentially associated with cardiovascular outcomes and allcause mortality in the community. J Am Heart Assoc. 2015;4(10): e002071. https://doi.org/10.1161/JAHA.115.002071.

59. Kuznetsova T, Cauwenberghs N, Knez J, Yang WY, Herbots L, D'Hooge J, et al. Additive prognostic value of left ventricular systolic dysfunction in a population-based cohort. Circ Cardiovasc Imaging. 2016;9(7). https://doi.org/10.1161/CIRCIMAGING.116. 004661.

60. Stanton T, Leano R, Marwick TH. Prediction of all-cause mortality from global longitudinal speckle strain: comparison with ejection fraction and wall motion scoring. Circ Cardiovasc Imaging. 2009;2(5):356-64. https://doi.org/10.1161/CIRCIMAGING.109. 862334.

61. Kalam K, Otahal P, Marwick TH. Prognostic implications of global LV dysfunction: a systematic review and meta-analysis of global longitudinal strain and ejection fraction. Heart. 2014;100(21): 1673-80. https://doi.org/10.1136/heartjnl-2014-305538.

62. Biering-Sorensen T, Biering-Sorensen SR, Olsen FJ, Sengelov M, Jorgensen PG, Mogelvang R, et al. Global longitudinal strain by echocardiography predicts long-term risk of cardiovascular morbidity and mortality in a low-risk general population: the Copenhagen city heart study. Circ Cardiovasc Imaging. 2017;10(3). https://doi. org/10.1161/CIRCIMAGING.116.005521.

63. Lonn E, Shaikholeslami R, Yi Q, Bosch J, Sullivan B, Tanser P, et al. Effects of ramipril on left ventricular mass and function in cardiovascular patients with controlled blood pressure and with preserved left ventricular ejection fraction: a substudy of the Heart Outcomes Prevention Evaluation (HOPE) Trial. J Am Coll Cardiol. 2004;43(12):2200-6. https://doi.org/10.1016/j.jacc.2003.10.073.

64. Crendal E, Walther G, Vinet A, Dutheil F, Naughton G, Lesourd B, et al. Myocardial deformation and twist mechanics in adults with metabolic syndrome: impact of cumulative metabolic burden. Obesity (Silver Spring). 2013;21(12):E679-86. https://doi.org/10. 1002/oby.20537.

65. Wong CY, O'Moore-Sullivan T, Leano R, Byrne N, Beller E, Marwick TH. Alterations of left ventricular myocardial characteristics associated with obesity. Circulation. 2004;110(19):3081-7. https://doi.org/10.1161/01.CIR.0000147184.13872.0F.

66. Wang J, Khoury DS, Yue Y, Torre-Amione G, Nagueh SF. Preserved left ventricular twist and circumferential deformation, but depressed longitudinal and radial deformation in patients with diastolic heart failure. Eur Heart J. 2008;29(10):1283-9. https://doi. org/10.1093/eurheartj/ehn141.

67. De Keulenaer GW, Brutsaert DL. Systolic and diastolic heart failure are overlapping phenotypes within the heart failure spectrum. Circulation. 2011;123(18):1996-2004; discussion 5. https://doi. org/10.1161/CIRCULATIONAHA.110.981431.

68. Maciver DH, Townsend M. A novel mechanism of heart failure with normal ejection fraction. Heart. 2008;94(4):446-9. https:// doi.org/10.1136/hrt.2006.114082.

69. Tan YT, Wenzelburger F, Lee E, Heatlie G, Leyva F, Patel K, et al. The pathophysiology of heart failure with normal ejection fraction: exercise echocardiography reveals complex abnormalities of both systolic and diastolic ventricular function involving torsion, untwist, and longitudinal motion. J Am Coll Cardiol. 2009;54(1): 36-46. https://doi.org/10.1016/j.jacc.2009.03.037.

70. Choi EY, Rosen BD, Fernandes VR, Yan RT, Yoneyama K, Donekal S, et al. Prognostic value of myocardial circumferential strain for incident heart failure and cardiovascular events in asymptomatic individuals: the Multi-Ethnic Study of Atherosclerosis. Eur Heart J. 2013;34(30):2354-61. https://doi.org/10.1093/eurheartj/ eht133.

71. Kuznetsova T, Herbots L, Richart T, D'Hooge J, Thijs L, Fagard $\mathrm{RH}$, et al. Left ventricular strain and strain rate in a general population. Eur Heart J. 2008;29(16):2014-23. https://doi.org/10.1093/ eurheartj/ehn280.

72. Aurigemma GP, Zile MR, Gaasch WH. Contractile behavior of the left ventricle in diastolic heart failure: with emphasis on regional systolic function. Circulation. 2006;113(2):296-304. https://doi. org/10.1161/CIRCULATIONAHA.104.481465.

73. Borlaug BA, Lam CS, Roger VL, Rodeheffer RJ, Redfield MM. Contractility and ventricular systolic stiffening in hypertensive heart disease insights into the pathogenesis of heart failure with preserved ejection fraction. J Am Coll Cardiol. 2009;54(5):410-8. https://doi.org/10.1016/j.jacc.2009.05.013.

74. Jeung MY, Germain P, Croisille P, El ghannudi S, Roy C, Gangi A. Myocardial tagging with MR imaging: overview of normal and pathologic findings. Radiographics. 2012;32(5):1381-98. https:// doi.org/10.1148/rg.325115098.

75. Dong SJ, Hees PS, Huang WM, Buffer SA Jr, Weiss JL, Shapiro EP. Independent effects of preload, afterload, and contractility on left ventricular torsion. Am J Phys. 1999;277(3):H1053-60. https:// doi.org/10.1152/ajpheart.1999.277.3.H1053.

76. Cameli M, Lisi M, Righini FM, Massoni A, Mondillo S. Left ventricular remodeling and torsion dynamics in hypertensive patients. Int J Cardiovasc Imaging. 2013;29(1):79-86. https://doi.org/10. 1007/s10554-012-0054-0.

77. Takeuchi M, Borden WB, Nakai H, Nishikage T, Kokumai M, Nagakura T, et al. Reduced and delayed untwisting of the left ventricle in patients with hypertension and left ventricular hypertrophy: a study using two-dimensional speckle tracking imaging. Eur Heart J. 2007;28(22):2756-62. https://doi.org/10.1093/eurheartj/ehm440.

78. Celic V, Tadic M, Suzic-Lazic J, Andric A, Majstorovic A, Ivanovic B, et al. Two- and three-dimensional speckle tracking analysis of the relation between myocardial deformation and functional capacity in patients with systemic hypertension. Am J Cardiol. 2014;113(5):832-9. https://doi.org/10.1016/j.amjcard. 2013.11.031.

79. Nagel E, Stuber M, Burkhard B, Fischer SE, Scheidegger MB, Boesiger $\mathrm{P}$, et al. Cardiac rotation and relaxation in patients with aortic valve stenosis. Eur Heart J. 2000;21(7):582-9. https://doi. org/10.1053/euhj.1999.1736.

80. Takeuchi M, Nishikage T, Nakai H, Kokumai M, Otani S, Lang RM. The assessment of left ventricular twist in anterior wall myocardial infarction using two-dimensional speckle tracking imaging. J Am Soc Echocardiogr. 2007;20(1):36-44. https://doi.org/10. 1016/j.echo.2006.06.019.

81. Sun JP, Lam YY, Wu CQ, Yang XS, Guo R, Kwong JS, et al. Effect of age and gender on left ventricular rotation and twist in a large group of normal adults-a multicenter study. Int J Cardiol. 2013;167(5):2215-21. https://doi.org/10.1016/j.ijcard.2012.06. 017.

Publisher's Note Springer Nature remains neutral with regard to jurisdictional claims in published maps and institutional affiliations. 